\title{
Generalized eruptive histiocytoma: a rare disease in an elderly patient
}

Histiocitoma eruptivo generalizado: doença rara em paciente idoso

\author{
Fernanda Cardoso ${ }^{1}$ \\ Brisa Dondoni Reis ${ }^{1}$ \\ José Augusto da Costa Nery²
}

\author{
Natália Battisti Serafini ${ }^{1}$ \\ Mónica Daniela Gauto Nuñez ${ }^{1}$ \\ Omar Lupi ${ }^{3}$
}

\begin{abstract}
Generalized eruptive histiocytoma is considered an extremely rare subtype of non-Langerhans cells histiocytosis. In the literature, there are few reports of this disease that mainly affects adults. In this report, we present a case of generalized eruptive histiocytoma in an elderly patient who had presented symptoms for over two months. Multiple erythematous papules, asymptomatic and symmetrically distributed were observed on the trunk and limbs. Histological examination showed a dense mononuclear cell dermal infiltrate. In the immunohistochemical analysis, the cells were CD68 positive, but CD1a, S100 and CD34 negative. A diagnosis of generalized eruptive histiocytoma was established. The aim of our paper is to report a case of a very rare disease, whose subtype and affected age group are even more unusual. Keywords: Histiocytoma; Histiocytosis; Histiocytosis, non-Langerhans-cell

Resumo: O histiocitoma eruptivo generalizado é considerado um subtipo extremamente raro de histiocitose de células não-Langerhans. Na literatura, existem poucos relatos sobre a doença que afeta principalmente adultos. Neste relato apresentamos um caso de histiocitoma eruptivo generalizado em um paciente idoso com sintomas há dois meses. Clinicamente observavam-se pápulas eritematosas múltiplas, assintomáticas, simetricamente distribuídas no tronco e membros. $\mathrm{O}$ exame histopatológico mostrou uma infiltração de células mononucleares densa na derme. $\mathrm{Na}$ análise imunohistoquímica, as células foram positivas para CD68, mas negativas para CD1a, CD34 e S100. O objetivo do nosso trabalho é relatar um caso de uma doença muito rara, cujos subtipo e faixa etária afetados são ainda mais incomuns. Palavras-chave: Histiocitoma; Histiocitose; Histiocitose de células não Langerhans
\end{abstract}

\section{INTRODUCTION}

Generalized eruptive histiocytoma (GEH) is an extremely rare and benign proliferative disorder of the skin, affecting mainly adults. ${ }^{1}$ It was first described in 1963 by Winkelmann and Müller. ${ }^{2}$ It is currently classified by the Histiocytosis International Society as a non-Langerhans cells histiocytosis (NLCH) and it is also known as histiocytosis non-X, or class II. ${ }^{3,4}$

GEH is characterized by multiple asymptomatic and symmetrically distributed brownish erythematous papules particularly involving the axial regions as trunk, face and proximal extremities. The mucous membranes and viscera are usually spared..$^{3,5,6}$ The diagnosis is made by histopathological and immunohistochemical exams and the differential diagnosis includes Langerhans cell histiocytosis, urticaria pigmentosa and other NLCH.

Since the disease is extremely rare, studies are difficult to perform, limiting the understanding of the

\footnotetext{
Received on 17.09.2011.

Approved by the Advisory Board and accepted for publication on 17.12.2011.

* Study carried out at Oswaldo Cruz Foundation (Fundação Oswaldo Cruz - FIOCRUZ) - Rio de Janeiro (RJ), Brazil.

Conflict of interest: None

Financial funding: None

MD - Graduate Course of Dermatology at the General Polyclinic of Rio de Janeiro (Policlínica Geral do Rio de Janeiro - PGRJ) - Rio de Janeiro (RJ), Brazil $\mathrm{PhD}$ in Medicine (Infectious and Parasitic Diseases) from the Federal University of Rio de Janeiro (Universidade Federal do Rio de Janeiro - UFRJ). Associate Researcher - Department of Mycobacterioses - Hansen's Disease Laboratory - Oswaldo Cruz Foundation (Fundação Oswaldo Cruz - FIOCRUZ) - Rio de Janeiro (RJ), Brazil

PhD in Medicine (Dermatology) from the Federal University of Rio de Janeiro (Universidade Federal do Rio de Janeiro - UFRJ). Post-doctoral degree from the University of Texas Medical Branch (Galveston/TX between 2001 and 2002). Adjunct Professor of Dermatology at the Federal University oif the State of Rio de Janeiro (Universidad e Federal do Estado do Rio de Janeiro - UNIRIO). Permanent Lecturer of Graduate Studies in Dermatology at the Federal University of Rio de Janeiro (Universidade Federal do Rio de Janeiro - UFRJ). Full Professor and Head if the Dermatology Service of the General Polyclinic of Rio de Janeiro (Policlínica Geral do Rio de Janeiro - PGRJ) - Rio de Janeiro (RJ), Brazil
} 
disease and therapeutic options. We present this case in order to improve the understanding of the disease and increase the interest of researchers.

\section{CASE REPORT}

A 79-year-old white man from Alagoas presented with a two-month-history of multiple asymptomatic disseminated erythematous papules. The dermatological examination showed erythematous papules, symmetrically distributed and widespread on the tegument, some in clusters, more evident on the dorsal aspect of the trunk and limbs (Figures 1 and 2). The scalp, mucous membranes, palms and soles were spared. The patient had no systemic signs or symptoms, and lesion sensitivity was preserved.

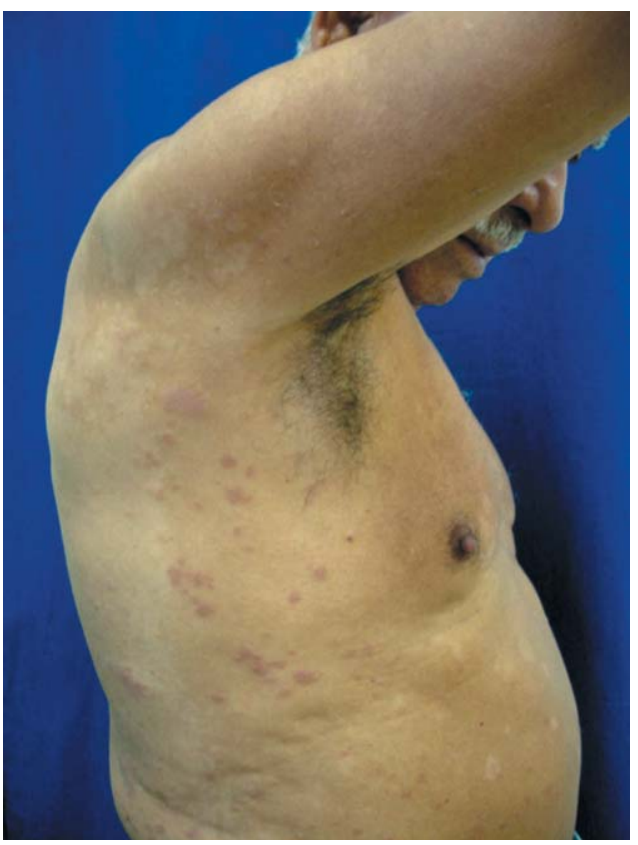

FIGURE 1: Erythematous papules on lateral region of the trunk

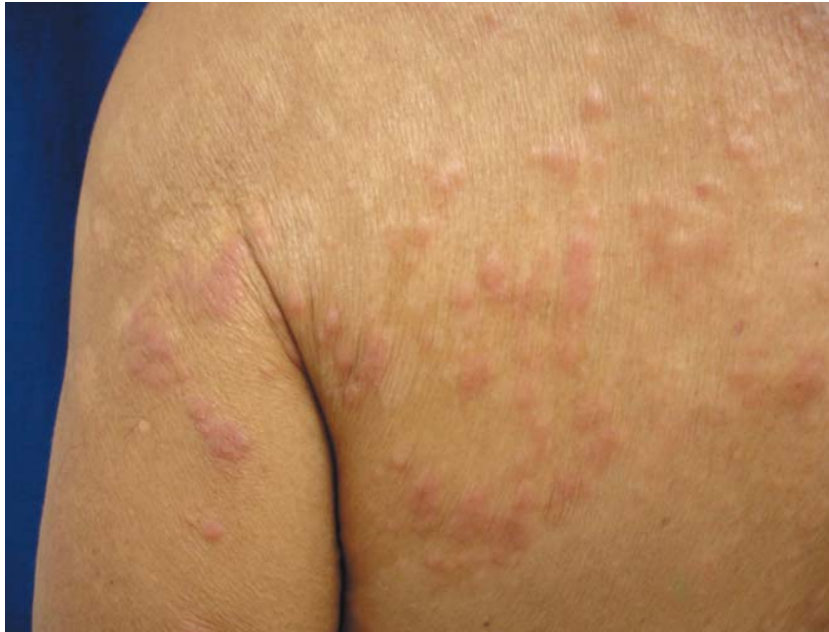

FiguRE 2: Erythematous papules more evident on upper trunk
Considering the differential diagnosis of syphilis and leprosy, specific laboratory tests were performed and the results were negative. Skin biopsy showed dense mononuclear dermal infiltrate without atypia, occupying the entire dermis, and perivascular lymphocyte clusters on the superficial dermis (Figure 3). Wade staining was negative. The immunohistochemical examination was positive only for $\mathrm{CD} 68$ and negative for CD1a, CD34 and S100 (Figure 4).

The diagnosis of GEH was based on the association of clinical, histopathological and immunohistochemical findings. The lesions regressed spontaneously after two months and he has no history of recurrence to date.

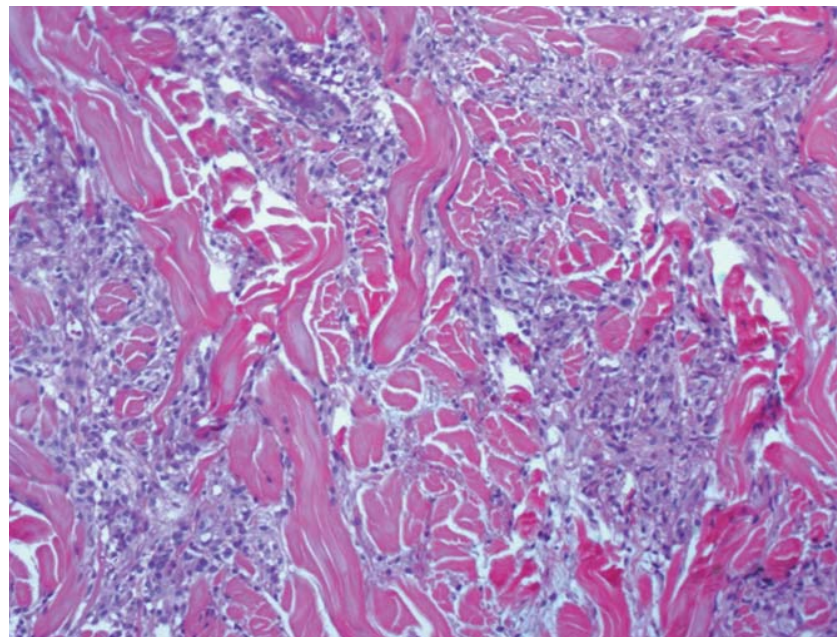

Figure 3: Dense mononuclear dermal infiltrate without atypia, occupying the entire dermis, associated with perivascular lymphocyte clusters on the superficial dermis

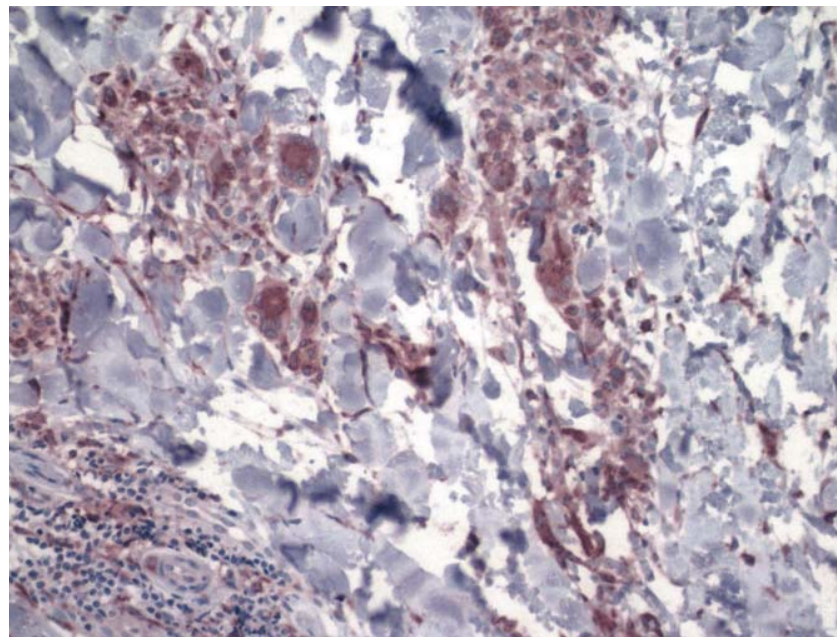

FIgURE 4: The immunohistochemical examination was positive for $\mathrm{CD} 68$ 


\section{DISCUSSION}

Histiocytoses represent a group of proliferative disorders of the mononuclear phagocyte and immunoregulatory effector system (M-PIRE) composed by macrophages and dendritic cells. ${ }^{6}$ The macrophages constitute the phagocytic function and the dendritic cells, represented by Langerhans cells, indeterminate cells and the dermal dendrocytes, constitute the antigens presentation. ${ }^{3,6}$ In 1987 the "Writing Group of the Histiocyte Society" presented the first classification of histiocytoses. Revised in 1997, this classification was divided into three classes: class I - dendritic cell-related histiocytosis (including Langerhans cell histiocytosis), class II - macrophage related histiocytosis and class III - malignant histiocytosis with monocyte infiltration. ${ }^{1,3}$

GEH is a benign and rare type of NLCH, characterized by brownish or reddish grouped papules, symmetrically distributed on the face, trunk and proximal extremities, frequently evolving to flares. The lesions are rarely seen on the mucous membranes. They tend to resolve spontaneously, and may regress with some residual hyperchromic macules. ${ }^{3,5,7,8}$ The disorder primarily affects adults, but it can also affect children in rare instances. ${ }^{1,8}$

According to Wee et al., approximately 31 cases had been reported in the literature by the year $2000 .{ }^{5}$ Bolognia et al. describes the existence of 35 cases in its latest edition of $2010 .^{3}$

The differential diagnosis among the NLCH is based primarily on the duration and course of lesions, patient age and presence or absence of associated systemic diseases. ${ }^{4}$

Bringing together the clinical, histopathological and immunohistochemical findings, the diagnosis of our patient was compatible with GEH.

Negative immunohistochemistry results for CD1a, CD34 and S100 markers and the absence of Birbeck granules rule out the diagnosis of Langerhans cell histiocytosis.4 Benign Cephalic Histiocytosis is characterized by childhood onset and involvement of the face and upper trunk, representing a different pattern in comparison with that of our patient. Papular xanthoma, disseminated xanthoma (DX) and juvenile xanthogranuloma (JXG) were not considered as possible diagnoses for our patient, because of the color of the lesions and the absence of Touton giant cells. ${ }^{6.9}$

Recent medical literature has suggested that GEH may be considered as the initial spectrum for several histiocytoses, mainly for sharing clinical and immunophenotypical similarities. ${ }^{4,5,9}$ GEH is an early undifferentiated stage of various histiocytic disorders. It may precede the classical presentation of JXG, DX, progressive nodular histiocytosis and/or multicentric reticulohistiocytosis. ${ }^{5,89}$ It is occasionally associated with neoplasias such as cutaneous T-cell lymphoma and acute monocytic leukemia. ${ }^{1}$

As previously mentioned, the disease is self-limiting and does not produce systemic symptoms, therefore there is no need for treatment. ${ }^{3,7,8}$ Lan et al. observed partial regression of lesions after 10 sessions of PUVA therapy, leaving some hyperpigmented papules and at the end of 20 sessions, there was complete regression without recurrence. ${ }^{1}$ Kwinter et al. used oral isotretinoin in patients with a three-month evolution of GEH, which resulted in resolution of the disease without recurrence over eight months of treatment, although new lesions have appeared later. ${ }^{10}$

Monitoring is recommended due to case reports of patients who developed other severe forms of histiocytosis, such as disseminated xanthoma. ${ }^{3}$

Considering the above facts, the authors conclude that non-Langerhans cell histiocytoses represent a field with few studies in dermatology, being limited to few reported cases, demanding the evaluation of therapeutic possibilities and the performation of randomized trials. $\square$

\section{ACKNOWLEDGEMENTS:}

We thank Dr. Alice de Miranda Machado for her valuable assistance in this study. She is graduated from Medical Science College - UERJ, MD in Pathology by UFRJ and PhD in Parasite Biology by FIOCRUZ. She is currently an Associate Researcher of the Hansen's Disease Laboratory in Fundação Oswaldo Cruz - FIOCRUZ - RJ. 


\section{REFERENCES}

1. Lan Ma H, Metze D, Luger TA, Steinhoff M. Successful treatment of generalized eruptive histiocytoma with PUVA. J Dtsch Dermatol Ges. 2007:5:131-4.

2. Winkelmann RK, Muller SA. Generalized eruptive histiocytoma: a benign papular histiocytic reticulosis. Arch Dermatol. 1963;88:586-96.

3. Goodman WT, Barrett TL. Histiocytoses. In: Bolognia JL, Jorizzo JL, Rapini RP Dermatology. 2. ed. Rio de Janeiro: Elsevier; 2010. p.1395-410.

4. Vázquez-Blanco M, Peteiro C, Toribio J. Generalized eruptive histiocytoma. Actas Dermosifiliogr. 2006;97:35-8

5. Wee SH, Kim HS, Chang SN, Kim DK, Park WH. Generalized eruptive histiocytoma: a pediatric case. Pediatr Dermatol. 2000;17:453-5.

6. Luz FB, Gaspar AP, Kalii-Gaspar N, Ramos-e-Silva M. Os histiócitos e as histiocitoses não Langerhans em Dermatologia. An Bras Dermatol. 2003;78:99-118.

7. Bajaj DR, Iqbal MP. Generalized eruptive histiocytosis presenting with warty lesions on face. J Coll Physicians Surg Pak. 2008;18:110-2.

8. Kiliç A, Cakmak SK, Gönül M, Gül U, Demirel 0, Demiriz M. Generalized eruptive histiocytoma: a pediatric case. Eur J Dermatol. 2006;16:694-5.
9. Marzano AV, Facchetti M, Caputo R. Guess what!Generalized eruptive histiocytosis (histiocytoma). Eur J Dermatol. 2002;12:205-6.

10. Kwinter J, DeKoven J. Generalized eruptive histiocytoma treated with isotretinoin. J Cutan Med Surg. 2009;13:146-50.

MAILING ADDRESS:

Fernanda Cardoso

Rodovia Comandante João Ribeiro de Barros,

Km 225/226

17039 800. Bauru-SP

E-mail:drafecardoso@botmail.com

How to cite this article: Cardoso F, Serafini NB, Reis BD, Nuñez MDG, Nery JAC, Lupi O. Generalized eruptive histiocytoma: a rare disease an elderly patient. An Bras Dermatol. 2013;88(1):105-8. 